JURNAL KETAHANAN NASIONAL

Vol. 25, No. 3, Desember 2019, Hal 348-372

DOI:http://dx.doi.org/ 10.22146/jkn.49812

ISSN:0853-9340(Print), ISSN:2527-9688(Online)

Online sejak 28 Desember 2015 di :http://jurnal.ugm.ac.id/JKN

VOLUME 25

No. 3, Desember 2019

Halaman 348-372

\title{
Transformasi Industri Kreatif Batik Dalam Rangka \\ Peningkatan Ketahanan Kerajinan Kain Batik \\ (Studi di Dusun Giriloyo, Desa Wukirsari, Kecamatan Imogiri, Kabupaten Bantul, Daerah Istimewa Yogyakarta)
}

\author{
Darto Wahidin \\ Universitas Negeri Surabaya \\ Email: dartowahidin2@gmail.com \\ Armaidy Armawi \\ Program Studi Ketahanan Nasional \\ Email: armaidy@ugm.ac.id
}

\author{
Kodiran \\ Fakultas Ilmu Budaya \\ Email: kodiran@ugm.ac.id
}

\begin{abstract}
This study aimed to described the transformation of the batik creative industry and identified the impact of the transformation of the batik creative industry in order to increased the resilience of batik fabric crafts in Giriloyo Hamlet, Wukirsari Village, Imogiri District, Bantul Regency, Special Region of Yogyakarta.

This type of research used a qualitative approach, the research design used was phenomenology. The determination of the informants in this study was carried out by means of a purposive sampling that was chosen with specific considerations and objectives. Data obtained from various sources namely, observation, in-depth interviews, documentation, and online studies. Data analysis in this study refered to the interactive analysis model proposed by Miles and Huberman.

The results of this study found that the transformation that occurred in Giriloyo batik could be seen from the development of Giriloyo batik before and now that caused the transformation in the Giriloyo batik fabric craft. Forms of transformation that occured in the grip, motives, colors, marketing, and economics. During this time entrepreneurs and craftsmen in transforming the craft of batik cloth were facing various kinds of challenges. The results of transformation could be seen in the development of Giriloyo batik motifs and colors that had experienced combinations. The impact of the Giriloyo batik motif transformation on the resilience of batik fabric crafts could be seen from the increased production of batik fabrics and a more secure welfare. However, on the other hand there was pollution caused by the waste of the batik industry and the plagiarism of batik cloth. The strategy in increasing the resilience of Giriloyo batik fabric craft was carried out to faced the onslaught of batik originating from abroad, so that Giriloyo batik fabric craft could survive and be competitive.
\end{abstract}

Keywords: Batik, Creative Industries, Craft Resilience, Transformation 
Darto Wahidin, Armaidy Armawi, Kodiran -- Transformasi Industri Kreatif Batik Dalam Rangka Peningkatan Ketahanan Kerajinan Kain Batik (Studi di Dusun Giriloyo, Desa Wukirsari, Kecamatan Imogiri, Kabupaten

Bantul, Daerah Istimewa Yogyakarta)

\begin{abstract}
ABSTRAK
Penelitian ini mempunyai tujuan untuk mendeskripsikan transformasi industri kreatif batik dan mengidentifikasi dampak transformasi industri kreatif batik dalam rangka peningkatan ketahanan kerajinan kain batik di Dusun Giriloyo, Desa Wukirsari, Kecamatan Imogiri, Kabupaten Bantul, Daerah Istimewa Yogyakarta.

Jenis penelitian ini menggunakan pendekatan kualitatif, desain penelitian yang digunakan fenomenologi. Penentuan informan dalam penelitian ini dilakukan dengan cara purposive sampling yang dipilih dengan pertimbangan dan tujuan tertentu. Data diperoleh dari berbagai sumber, yakni observasi, wawancara mendalam, dokumentasi, dan studi online. Analisis data dalam penelitian ini mengacu pada model analisis interatif yang dikemukakan oleh Miles dan Huberman.

Hasil penelitian ini menemukan bahwa transformasi yang terjadi pada batik Giriloyo dapat dilihat dari perkembangan batik Giriloyo dulu dan sekarang yang menyebabkan terjadinya transformasi pada kerajinan kain batik Giriloyo. Bentuk transformasi yang terjadi pada pakem, motif, warna, pemasaran, dan ekonomi. Selama ini pengusaha dan perajin dalam mentransformasi kerajinan kain batik tersebut menghadapi berbagai macam tantangan. Hasil transformasi bisa dilihat pada pengembangan motif dan warna batik Giriloyo yang telah mengalami kombinasi. Dampak dari adanya transformasi motif batik Giriloyo terhadap ketahanan kerajinan kain batik dapat dilihat dari adanya peningkatan produksi kain batik dan kesejahteraan yang lebih terjamin. Namun, di sisi lain terjadinya pencemaran akibat limbah industri batik dan adanya penjiplakan kain batik tulis. Strategi dalam peningkatan ketahanan kerajinan kain batik Giriloyo dilakukan untuk menghadapi gempuran batik yang berasal dari luar negeri, agar kerajinankain batik Giriloyo tetap bertahan dan dapat bersaing.
\end{abstract}

Kata Kunci: Batik, Industri Kreatif, Ketahanan Kerajinan, Transformasi.

\section{PENGANTAR}

Modernisasi dapat dilihat dari fenomena dalam kehidupan sehari-hari, di antaranya adanya budaya tradisional yang mengalami marginalisasi; semakin banyak negara yang lepas dari penjajahan, kemudian tumbuhnya negara-negara demokrasi semakin diakuinya hak-hak asasi manusia; dalam bidang ekonomi ditandai dengan kebutuhan manusia akan barang dan jasa yang semakin kompleks; pada bidang sosial ditandai dengan kelompok baru dalam masyarakat semakin banyak; adanya perluasan bidang pekerjaan dan pemisahannya dengan kehidupan keluarga; dan pertumbuhan kemandirian keluarga dan pemisahannya kontrol sosial komunitas atau masyarakat yang lebih luas (Martono, 2014: 175).

Batik merupakan salah satu fenomena yang mengalami modernisasi dalam kebudayaan tradisional. Kerajinan kain batik dikarakterkan sebagai salah satu perangkat dari modernitas.

Batik saat ini telah mengalami pergeseran (shifting) dan transformasi (transformation) pada pakem-pakem tradisionalnya. Pakem yang telah mengalami transformasi tersebut berdampak terhadap berbagai macam motif dan warna pada batik tersebut, sehingga dalam perkembangannya muncul batik modern atau kontemporer yang tak lagi berpedoman pada pakem-pakem tradisionalnya. Padahal dalam pakem-pakem tradisional terdapat filosofi atau nilai-nilai kehidupan. Masyarakat (society) kini lebih menyukai batik dengan warnawarna yang cerah daripada warna-warna tua. Tidak jarang pengusaha dan perajin batik pun mengabaikan pakem-pakem tradisionalnya demi untuk memenuhi tuntutan dari permintaan konsumen (consumer) dan pasar (market). Permintaan konsumen (consumer) dan pasar (market) turut memberikan pengaruh terhadap perjalanan gelombang ekonomi dunia.

Perjalanan gelombang ekonomi dunia saat ini setidaknya dapat diklasifikasikan menjadi 4 (empat) gelombang, yaitu gelombang pertama ekonomi yang bertumpu pada sektor pertanian; gelombang kedua 
bertumpu pada sektor industri; gelombang ekonomi yang bertumpu pada sektor informasi; dan gelombang ekonomi yang bertumpu pada sektor ekonomi kreatif (Purwaningsih, 2010; Haerisma, 2018). Ekonomi kreatif merupakan sebuah konsep di era saat ini, yang mengintensifkan informasi dan kreativitas dengan mengandalkan ide dan kreativitas dengan mengandalkan ide dan pengetahuan dari sumber daya manusia sebagai faktor produksi yang utama. Konsep ini biasanya akan didukung dengan keberadaan industri kreatif yang menjadi pengejawantahannya. Seiring dengan berjalannya waktu, perkembangan ekonomi sampai pada taraf industri kreatif setelah beberapa waktu sebelumnya, dunia dihadapi dengan konsep gelombang ekonomi informasi yang mana informasi menjadi hal yang utama dalam pengembangan ekonomi (Oakley, 2009).

Klasifikasi industri kreatif yang ditetapkan oleh setiap negara di dunia ini berbeda-beda. Pengklasifikasian industri kreatif tergantung pada tujuan analitik dan potensi suatu negara tersebut. Industri kreatif yang dikembangkan oleh Pemerintah Republik Indonesia telah menetapkan sebanyak 14 sub sektor industri kreatif. Dari 14 sub sektor pada industri kreatif, batik bisa masuk dalam sub sektor seni, kerajinan, maupun fashion. Pengembangan industri kerajinan kain batik di Indonesia tidaklah mudah, terdapat beberapa masalah (problems) yang terkait dengan kemungkinan pengembangan yang dapat dilakukan.

Batik di Indonesia merupakan kombinasi duahal, sebagai industri (industry) dan kerajinan (craft). Dari sisi industri, pengembangan industri batik sebenarnya sangat terkait dengan industri tekstil Indonesia yang saat ini mengalami persaingan kuat terutama dengan China. Rendahnya harga produk China menjadikan tekstil Indonesia kurang diminati, dan tidak mampu bersaing untuk pasar dalam negeri sendiri. Industri tekstil ini kurang beruntung termasuk keberadaannya cukup terancam. Globalisasi ekonomi yang mengharuskan Indonesia menghapuskan hambatan perdagangan baik tarif maupun non-tarif, termasuk pada produk tekstil telah mengancam keberadaan industri tekstil, baik dalam industri kain maupun industri garmen.

Pada sisi yang lain, batik Indonesia tetaplah menjadi produk kerajinan yang sangat tergantung pada proses kreativitas perajin batik, untuk membuat desain, mengembangkan jenis kain, dan memasarkannya secara eksklusif. Ketika batik menjadi suatu produk kerajinan, maka kualitas menjadi hal yang utama. Segmen pasarnya pun akan menjadi berbeda dan akan menentukan tingkat harga yang berbeda pula. Namun, sayangnya hal ini belum menjadi kesadaran umum perajin batik di Indonesia, yang cenderung menganggap pekerjaan membatik hanyalah bersifat turun temurun, sehingga tidak perlu melakukan inovasi desain produk dan cukup hanya membuat ulang berdasarkan desain-desain tradisional yang sudah ada.

Saat ini batik yang merupakan pakaian, keberadaannya tidak bisa dilepaskan dalam perkembangan fashion, yang merupakan bagian dari industri kreatif. Secara nasional di Indonesia industri kreatif menduduki peringkat ketujuh dari sepuluh lapangan usaha utama (Haerisma, 2018: 92). Selain itu, pemerintah melalui Departemen Perdagangan Republik Indonesia (2008) telah memberikan perhatian yang lebih terhadap keberadaan industri kreatif ini, seperti: pelatihan, pendampingan, dan penyediaan tenaga ahli bagi tumbuhnya industri kreatif di Indonesia. 
Darto Wahidin, Armaidy Armawi, Kodiran -- Transformasi Industri Kreatif Batik Dalam Rangka Peningkatan Ketahanan Kerajinan Kain Batik (Studi di Dusun Giriloyo, Desa Wukirsari, Kecamatan Imogiri, Kabupaten Bantul, Daerah Istimewa Yogyakarta)

Daerah Istimewa Yogyakarta merupakan salah satu daerah yang terkenal dengan batiknya. Industri kreatif batik merupakan salah satu sub sektor kerajinan yang sangat potensial untuk dikembangkan di wilayah Daerah Istimewa Yogyakarta. Kerajinan sebagai salah satu sub sektor dalam industri kreatif memiliki kontribusi yang cukup tinggi terhadap perekonomian Indonesia, khususnya lagi terhadap Daerah Istimewa Yogyakarta. Batik Yogyakarta mempunyai keunikan tersendiri dibandingkan dengan batik yang berasal dari Solo, Pekalongan, maupun Cirebon. Keunikan tersebut dikenal sebagai batik keraton karena mempunyai Keraton Ngayogyakarta, sehingga mendapat pengaruh sangat besar terhadap pakem, motif, dan warna pada batik Yogyakarta itu sendiri. Selama ini sentra batik tulis Daerah Istimewa Yogyakarta yang terbesar berada pada tiga dusun yang ada di Desa Wukirsari, Kecamatan Imogiri, Kabupaten Bantul. Tiga dusun tersebut yang paling banyak perajinnya ada di Dusun Giri loyo.

Bertolak dari uraian masalah di atas, oleh karena itu penelitian ini dipandang penting (urgent) untuk melihat transformasi industri kreatif batik dan dampak transformasi industri kreatif batik terhadap peningkatan ketahanan kerajinan kain batik. Berdasarkan latar belakang yang telah dikemukakan di atas dapat dirumuskan permasalahan sebagai berikut: (1). Bagaimana transformasi industri kreatif batik di Dusun Giriloyo, Desa Wukirsari, Kecamatan Imogiri, Kabupaten Bantul, Daerah Istimewa Yogyakarta; (2). Bagaimana dampak transformasi industri kreatif batik dalam rangka peningkatan ketahanan kerajinan kain batik di Dusun Giriloyo, Desa Wukirsari, Kecamatan Imogiri, Kabupaten Bantul, Daerah Istimewa Yogyakarta?. Tujuan dalam penelitian ini untuk mendeskripsikan transformasi industri kreatif batik dan mengidentifikasi dampak transformasi industri kreatif batik dalam rangka peningkatan ketahanan kerajinan kain batik di Dusun Giriloyo, Desa Wukirsari, Kecamatan Imogiri, Kabupaten Bantul, Daerah Istimewa Yogyakarta.

Pola penelitian terkait dengan industri kreatif yang menjadi objeknya pada batik, sebagaimana yang dilakukan di sini, merupakan pola penelitian yang telah cukup banyak dilakukan di Indonesia (lihat Rosalina dan Martinelli, 2013; Nurficahyanti, 2015; Maziyah, dkk., 2016; Wahidin dan Sarmini, 2016; Nursaid dan Armawi, 2016; Hikmah, 2017; Nurcahyanti dan Affanti, 2018). Meskipun demikian, penelitian tersebut umumnya tidak berlanjut pada upaya mendeskripsikan transformasi industri kreatif batik dan mengidentifikasikan dampaknya terhadap ketahanan kerajinan kain batik. Maka upaya itulah yang dilakukan dalam penelitian ini, agar terjadi perbedaan (difference) dan kebaharuan (novelty) dengan penelitian sebelumnya.

Sebagaimana yang dijelaskan oleh Soekamto (1984: 10-12), bahwa batik berasal dari Indonesia dan bermula dari Jawa. Kata "batik" berasal dari satu kata "tik". Kata "tik" artinya "titik", batik berarti titik. Kata batik dalam bahasa Jawa berasal dari kata "tik" yang mempunyai makna berhubungan dengan suatu pekerjaan halus, lembut, dan kecil yang mengandung unsur keindahan. The world batik is thought to be derived from the world "ambatik" which translated means'a cloth with little dots. The suffix "tik" means little dot, drop, point or to make dots (Steelyana, 2012: 118). Dalam membatik, tentunya mempunyai berbagai macam tujuan, setidaknya ada tiga tujuan dalam membatik, yaitu batik sebagai bagian dari adat; batik sebagai komoditas 
perdagangan; dan batik untuk ekspresi. Secara umum batik Yogyakarta termasuk ke dalam kelompok batik keraton, sebagai kelompok batik keraton karena di Yogyakarta sendiri terdapat Keraton Ngayogyakarta. Pengaruh keraton masih sangat kuat terhadap batik Yogyakarta itu sendiri.

Istilah dari transformasi sosial dan transformasi kebudayaan, keduanya pada dasarnya mempunyai perbedaan yang dapat dibedakan dengan membedakan secara tegas pengertian antara masyarakat dan kebudayaan. Sebagaimana yang dikatakan oleh Martono (2014: 12), bahwa transformasi sosial merupakan bagian dari transformasi budaya. Transformasi sosial meliputi transformasi dalam perbedaan usia, tingkat kelahiran, dan penurunan rasa kekeluargaan antaranggota masyarakat sebagai akibat terjadinya arus urbanisasi dan modernisasi. Sedangkan transformasi budaya menyangkut banyak aspek dalam kehidupan, seperti: kesenian, ilmu pengetahuan, teknologi, aturan-aturan hidup berorganisasi, dan filsafat. Sangatlah jelas bahwa transformasi budaya jauh lebih luas dibandingkan dengan transformasi sosial.

Transformasi sosial dan transformasi budaya yang terjadi dalam masyarakat saling berkaitan, tidak ada masyarakat yang tidak memiliki kebudayaan dan sebaliknya tidak ada kebudayaan tanpa masyarakat. Persamaan antara transformasi sosial dan transformasi kebudayaan keduanya berhubungan dengan masalah penerimaan cara-cara baru atau suatu transformasi terhadap cara-cara hidup manusia dalam memenuhi berbagai kebutuhannya. Kebudayaan mencakup segenap cara berpikir dan bertingkah laku yang timbul karena interaksi yang bersifat komunikatif, seperti: menyampaikan buah pikiran secara simbolis dan bukan muncul karena warisan biologis.
Pengusaha dan perajin batik Giriloyo secara tidak langsung berinteraksi ketika ada pameran sehingga memunculkan ide-ide, gagasan, dan pemikiran baru yang dituangkan ke dalam bentuk simbol dalam batik sehingga menyebabkan adanya transformasi dalam batik tersebut baik dari segi motif, warna, maupun yang lainnya. Departemen Perdagangan Republik Indonesia (2008) menyatakan bahwa industri kreatif merupakan industri yang berasal dari pemanfaatan kreativitas, keterampilan serta bakat individu untuk menciptakan kesejahteraan serta lapangan pekerjaan dengan menghasilkan dan mengeksploitasi daya kreasi dan daya cipta individu tersebut. Industri kreatif juga dikenal dengan nama lain industri budaya terutama di Eropa atau juga ekonomi kreatif. Sub sektor yang merupakan industri berbasis kreativitas di Indonesia berdasarkan pemetaan industri kreatif yang telah dilakukan oleh Departemen Perdagangan Republik Indonesia (2008), meliputi: periklanan, arsitektur, pasar barang seni, kerajinan, desain, fashion, video, film, fotografi, permainan interaktif, musik, seni pertunjukkan, penerbitan dan percetakan, layanan komputer dan peranti lunak, televisi dan radio, riset dan pengembangan, serta kuliner.

Secara orisinalitasnya teori kreativitas ini didasarkan pada dua pendekatan, yaitu: pendekatan secara mistis dan pendekatan spiritual yang dilihat dari kemungkinan dan ketidakmungkinan adanya ilmu tersebut (Sternberg, 1999: 3-13). Dalam bukunya Sternberg mengatakan bahwa kreativitas dimaknai sebagai kemampuan untuk memproduksi karya atau hal yang baru didasarkan pada orisinalitas dan tidak menjiplak dan cocok digunakan untuk memenuhi sebuah tugas (Sternberg, 1999: 3). 
Darto Wahidin, Armaidy Armawi, Kodiran -- Transformasi Industri Kreatif Batik Dalam Rangka Peningkatan Ketahanan Kerajinan Kain Batik (Studi di Dusun Giriloyo, Desa Wukirsari, Kecamatan Imogiri, Kabupaten Bantul, Daerah Istimewa Yogyakarta)

Kreativitas sebagai suatu kemampuan untuk menghasilkan karya yang mengandung unsur kebaruan termasuk di antaranya keaslian dan tidak terduga serta dapat berguna dan dapat disesuaikan dengan tuntutan tugas (Sternberg, 1999: 3). Pendapat mengenai kreativitas dari Sternberg tersebut menunjukkan bahwa kreativitas merupakan sesuatu yang berkenaan dengan kualitas produk atau penilaian dan respon yang bersifat kreatif melalui sejumlah pengamatan yang dilakukan oleh orang yang tepat.

Proses kreatif dalam berinovasi menurut Haryono (2008: 49-50) merupakan suatu inovasi yang secara konseptual-teoritis setidaknya memerlukan empat syarat, yaitu: resources, genius, need, dan opportunity. Esensi dari kreativitas itu untuk mencipta dengan menggunakan ide, gagasan, dan pikiran yang kreatif. Kreativitas juga melibatkan suatu proses yang dianggap mengandung nilai-nilai kreatif. Sesungguhnya kreativitas ini sebagai suatu hal yang menghasilkan ide baru oleh individu atau kelompok kecil. Wajar manakala batik Giriloyo yang dihasilkan oleh para pengusaha dan perajin dengan berbagai macam motif dan warnanya tersebut hasil dari sebuah kreativitas yang menciptanya tersebut dari ide, gagasan, dan pikiran. Kreativitas turut memberikan kontribusi terhadap budaya melalui sesuatu yang baru.

Dalam teori interaksionisme simbolik, aktor tidak dipandang sebagai manusia yang semata-mata responsif, melainkan aktor senantiasa menafsirkan dan mendefinisikan setiap tindakan orang lain. Menurut Poloma (2002: 50) interaksionisme simbolik dilakukan dengan menggunakan bahasa sebagai suatu simbol yang terpenting dan isyarat (decoding). Perspektif interaksionisme simbolik, respon aktor baik secara langsung maupun tidak langsung selalu didasarkan pada penilaian makna atas pengunaan simbol-simbol yang menjembatani interaksi manusia. Tindakan dan tanggapan aktor bukan hanya sekedar reaksi spontanitas belaka dari tindakan seseorang terhadap orang lain, melainkan didasarkan atas makna yang diberikan terhadap tindakan orang lain itu. Dalam melakukan tindakan tersebut seorang aktor saling terkait dengan tindakan manusia lainnya.

Simbol pun sebagai sesuatu yang dianggap atas dasar kesepakatan bersama sebagai sesuatu yang memberikan sifat alamiah atau mewakili, mengingatkan kembali dengan membayangkan dalam hati dan pikiran. Dalam kaitan tersebut, simbol dapat dipahami sebagai eskpresi dalam wujud material yang digunakan masyarakat untuk menggambarkan bentuk, sifat, dan makna yang dianut oleh masyarakat. Interaksionisme simbolik menunjukkan kepada sifat khas dari interaksi antar manusia, interaksi tersebut memiliki makna tersendiri bagi mereka di mana para pengusaha batik, perajin batik Giriloyo saling menterjemahkan dan mendefinisikan transformasi industri kreatif batik Giriloyo serta dampak dalam rangka peningkatan ketahanan kerajinan kain batik.

Industri kreatif kerajinan kain batik diharapkan dapat mengangkat citra masyarakat lokal dan bahkan regional dilihat dari kualitas produk dan model kerajinan kain batik yang dihasilkannya. Dimilikinya kemampuan terampil kreatif para perajin tersebut telah mendorong adanya suatu keinginan untuk meningkatkan ketahanan kerajinan kain batik untuk kesejahteraan diri, keluarga dan masyarakat setempat yang ada di sentra batik Giriloyo dengan memanfaatkan potensi berupa bahan alam yang ada di lingkungan sekitar, di dukung pengetahuan dan keterampilan 
teknologi yang dipelajarinya. Kerajinan kain batik sebagai salah satu produk budaya dari Daerah Istimewa Yogyakarta dalam perkembangannya pada saat ini dapat memberikan nilai budaya dan nilai ekonomis bagi masyarakat sekitar. Batik Giriloyo sebagai bagian dari kerajinan telah mengalami proses transformasi, hal ini disebabkan oleh modernisasi yang sedang menggerus. Diperlukan suatu kerangka peningkatan ketahanan kerajinan kain batik Giriloyo tersebut. Menjadi sangat penting (urgent) di era modernisasi ini, sebuah produk bangsa Indonesia bisa bertahan.

Penelitian ini menggunakan pendekatan kualitatif dan data yang digunakan dalam penelitianiniberupa deskriptif. MenurutCreswell (2013: 4), penelitian kualitatif merupakan metode-metode untuk mengeksplorasi dan memahami makna yang oleh sejumlah individu atau sekelompok orang dianggap berasal dari masalah sosial atau kemanusiaan. Desain penelitian yang digunakan dalam penelitian ini yakni fenomenologi. Sebagaimana yang dijelaskan oleh Creswell (2013: 20-21), bahwa fenomenologi memahami pengalamanpengalaman hidup manusia menjadikan filsafat fenomenologi sebagai suatu metode penelitian yang prosedur-prosedurnya mengharuskan peneliti untuk mengkaji sejumlah subjek dengan terlibat secara langsung dan relatif lama di dalamnya untuk mengembangkan pola-pola dan relasi-relasi makna. Penggunaan desain penelitian fenomenologi dipilih karena melalui desain ini akan membantu peneliti dalam memahami berbagai gejala transformasi dan pemaknaan (perspektif subjek) dalam berkreativitas dan berinovasi pada batik Giriloyo.

Lokasi penelitian ini berada di Dusun Giriloyo, Desa Wukirsari, Kecamatan
Imogiri, Kabupaten Bantul, Daerah Istimewa Yogyakarta. Alasan penelitian di Kampung Batik Giriloyo ini sebagai tempat penelitian karena Kampung Batik Giriloyo terkenal sebagai desa perajin batik di Daerah Istimewa Yogyakarta yang mempunyai jumlah perajin batik terbesar sekitar 600 -an perajin. Bahkan Kampung Batik Giriloyo ini sebagai salah satu pusat batik tulis terbesar di Daerah Istimewa Yogyakarta yang lokasinya strategis karena berada di Jalan Imogiri dan selalu ramai dipadati oleh pengunjung. Lokasi penelitian ini juga dulu dijadikan sebagai tempat pengambilan sampel untuk pengajuan di UNESCO sebelum ditetapkannya batik sebagai warisan budaya tak benda.

Penentuan informan dalam penelitian ini dilakukan secara purposive sampling yang dipilih dengan pertimbangan dan tujuan tertentu. Dalam hal ini informan penelitian ditentukan secara purposive sampling yang disebabkan karena orientasi penelitian dituju kepada pengusaha batik, perajin batik, dan konsumen batik Giriloyo. Total semua informan dalam penelitian ini berjumlah 16 informan, yang terdiri-dari: tiga aparat Desa Wukirsari, pengusaha batik Giriloyo yang diwawancarai sebanyak enam orang, perajin batik ada empat orang, dan konsumen yang diwawancarai ada tiga orang.

Teknik pengumpulan data yang diperoleh dalam penelitian ini dari berbagai sumber, yaitu: observasi (observation), wawancara mendalam (indepth interview), dokumentasi (documentation), dan studi online (online study), kemudian dilakukan pemilihan data secara selektif serta disesuaikan dengan permasalahan yang diangkat dalam penelitian ini yang terkait dengan transformasi industri kreatif batik dalam rangka peningkatan ketahanan kerajinan kain batik. Teknik 
Darto Wahidin, Armaidy Armawi, Kodiran -- Transformasi Industri Kreatif Batik Dalam Rangka Peningkatan Ketahanan Kerajinan Kain Batik (Studi di Dusun Giriloyo, Desa Wukirsari, Kecamatan Imogiri, Kabupaten Bantul, Daerah Istimewa Yogyakarta)

analisis data penelitian ini mengacu pada model analisis interatif yang dikemukakan oleh Miles dan Huberman (1992), the most serious and central difficulty in the use of qualitative data is that methods of analysis are not well formulate (yang paling serius dan menjadi pusat kesulitan dalam penggunaan data kualitatif terkait dengan metode analisis yang tidak terumuskan secara baik).

\section{PEMBAHASAN}

\section{Transformasi Industri Kreatif Batik Giriloyo}

Seperti halnya istilah struktur, istilah transformasi di sini juga berbeda pengertiannya dengan yang umum diberikan pada kata ini, yaitu perubahan. Pada dasarnya transformasi dalam konsepnya perubahan terkandung pengertian proses berubahnya sesuatu ke sesuatu yang lain dalam ruang dan waktu tertentu. Maka akan berbeda dengan transformasi (transformation) yang menunjuk pada berubahnya sesuatu tetapi (seolah-olah) tanpa melalui sebuah proses, atau proses tersebut tidak dipandang penting. Dalam konteks pembicaraan di sini transformasi diterjemahkan sebagai alih rupa atau malih dalam bahasa Jawa ngoko, artinya dalam suatu transformasi yang berlangsung merupakan sebuah perubahan pada tataran permukaan, sedangkan pada tataran yang lebih dalam lagi perubahan tersebut tidak terjadi (Putra, 2006: 61). Tentang transformasi, Daszko dan Sheinberg (2005) mengatakan bahwa untuk mentransformasi berarti melakukan perubahan dalam bentuk, tampilan, dan struktur.

Selama ini para pengusaha dan perajin yang sudah tua atau sepuh masih tetap membikin dan mempertahankan motif batik klasik, sehingga para perajin batik yang sudah tua tersebut hanya membikin motif dan warna itu-itu saja. Hal berbeda dilakukan oleh kalangan pengusaha dan perajin muda yang sudah melakukan sebuah perkembangan jauh lebih maju yakni dengan adanya proses transformasi pada batik Giriloyo tersebut. Misalnya batik klasik tapi dilakukan renov dengan cara diubah sedikit baik dari segi warnanya maupun adanya campuran pada motif batik klasik tersebut dengan motif batik lainnya. Dalam konteks tersebut telah terjadi sebuah transformasi pada batik Giriloyo tersebut. Dinamisnya perkembangan zaman tentunya memberikan pengaruh terhadap berbagai macam produk kerajinan, salah satunya kerajinan kain batik. Transformasi industri kreatif batik yang dilakukan tentunya ada berbagai macam sebabnya terhadap terjadinya transformasi industri kreatif batik Giriloyo. Bentuk dari transformasi industri kreatif batik Giriloyo dapat dilihat dari adanya transformasi pakem, motif, warna, pemasaran, sampai pada transformasi ekonomi.

\section{Sebab Transformasi Industri Kreatif Batik Giriloyo}

Proses terjadinya transformasi pada batik Giriloyo tentunya juga mempunyai berbagai macam sebabnya. Sebagaimana hasil di lapangan menunjukkan dari para informan, bahwa adanya transformasi pada batik Giriloyo tersebut memang untuk menarik konsumen, adanya permintaan pasar, mengikuti perkembangan zaman sekarang, adanya inovasi dari pengusaha dan perajin, adanya kreativitas dari pengusaha dan perajin, dan untuk melestarikan batik Giriloyo. Dari semuanya tersebut ternyata untuk menjadi magnet terhadap konsumen. Konsumen menjadi seorang raja sehingga pola pelayanan pun harus diberikan secara istimewa, manakala meminta sesuatu maka 
harus dapat dikabulkan dan dituruti. Di sini pula yang menjadi salah satu alasan bahwa batik Giriloyo dilakukan transformasi pada berbagai macam bentuknya tersebut untuk menarik konsumen yang merupakan seorang raja tersebut. Adanya transformasi tersebut juga agar membuat batik Giriloyo tidak menonton dan terus disukai oleh kalangan konsumen batik Giriloyo itu sendiri.

Pasar yang terus berkembang pesat dan terus mengalami transformasi dengan berbagai macam alasan tersebut, ternyata juga dipahami betul oleh kalangan pengusaha dan perajin batik Giriloyo. Maka dari itu batik yang selama ini dibuatnya tersebut harus dapat memenuhi dan mengikuti perkembangan pasar. Bagaimanapun juga bahwa batik tersebut akan dijual pada pasar, sehingga harus mengikuti selera pasar yang saat ini sedang berkembang. Perkembangan zaman yang begitu pesatnya saat ini dengan berbagai macam bentuknya tersebut haruslah dapat diikuti oleh semua kalangan, tak terkecuali oleh kalangan pengusaha dan perajin batik Giriloyo. Maka produk batik yang dihasilkannya juga harus dapat mengikuti perkembangan zaman agar dapat tetap disukai oleh kalangan konsumen. Perlu adanya suatu gebrakan yang terus dilakukan dalam membuat batik, tentunya referensi perkembangan zaman atau yang sedang terjual keras di pasaran harus terus dijadikan acuannya.

Gambar 1 menunjukkan transformasi batik tersebut bukanlah batik klasik karena menggunakan warna-warna yang cerah dan dapat dikatakan ngejreng (warna mencolok). Terlihat dari gambar tersebut dalam satu kain batik bisa menggunakan lebih dari tiga warna. Warna dasarannya juga sudah ditransformasikan dengan warna yang cerah. Bahkan pada motif-motifnya sudah dikombinasikan dengan motif lainnya, dalam satu kain batik sangat terlihat sekali menggunakan lebih dari tiga motif yang dikombinasikannya. Hal tersebut dilakukan sebagai salah satu daya tarik bagi para konsumen yang datang ke sentra batik Giriloyo dan dalam rangka mengikuti perkembangan pasar yang sedang berkembang.

Kejenuhan terhadap motif-motif klasik dari konsumen, sehingga membuat para pengusaha dan perajin membikin batik kontemporer, tapi tetap tidak meninggalkan motif klasiknya. Batik kontemporer sendiri merupakan perpaduan antara batik klasik dan batik modern. Para pengusaha dan perajin

Gambar 1

Warna Motif Batik Giriloyo Kontemporer

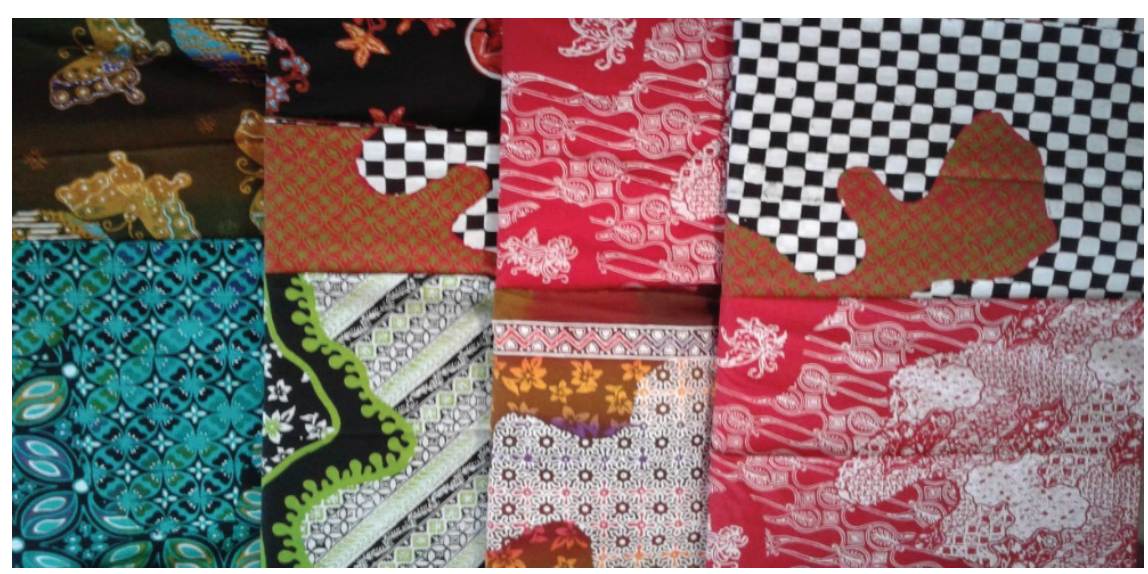

Sumber: Dokumentasi Darto Wahidin, 2018 
Darto Wahidin, Armaidy Armawi, Kodiran -- Transformasi Industri Kreatif Batik Dalam Rangka Peningkatan Ketahanan Kerajinan Kain Batik (Studi di Dusun Giriloyo, Desa Wukirsari, Kecamatan Imogiri, Kabupaten Bantul, Daerah Istimewa Yogyakarta)

mendapatkan ide-ide untuk melakukan kombinasi tersebut dari hasil lihat-lihat pameran dan mengikuti perkembangan batik zaman sekarang. Dari ide-ide tersebut akan dituangkan dalam kain batik yang akan mengkombinasi antara sebagian motif klasik dengan sebagian motif modern. Tujuan hal tersebut dilakukan biar nuansanya tidak terlalu tua atau tradisional banget dan sebagai pedagang batik maupun pembuat batik harus dapat mengikuti dari selera konsumennya.

Contoh yang tersajikan dalam gambar 2, merupakan jenis batik kontemporer. Kontemporer diartikan sebagai modern atau kekinian (Nurcahyanti dan Affanti, 2018: 394). Hasil karya ataupun produk yang dihasilkan berbeda dari sebelumnya. Perbedaan tersebut melibatkan serangkaian pertimbangan, proses, kebutuhan, selera, dan material yang digunakan. Dari gambar 2 tersebut sangat terlihat bahwa adanya transformasi pada warna dan motifnya. Warnawarna dalam motif-motif batik tersebut telah mengalami transformasi yakni berupa warna cerah ada merah, biru, hijau, putih, ungu, maupun orange. Namun, dasaran dalam kain batik tersebut masih menggunakan warna klasik yakni hitam dan putih. Sedangkan pada motifnya sangat jelas sekali adanya kombinasi dengan memadukan lebih dari tiga motif dalam satu kain batik. Secara kasat mata bagi para konsumen pasti motif batik tersebut sangat diminati karena menarik dari segi warnanya, atau istilahnya tidak menonton. Terkadang yang dilihat oleh seorang konsumen itu dari bentuk luarannya bukan dari kualitas produk batik tersebut, maka di sini konsumen akan tertipu.

Generasi muda kini lebih ekspresif terhadap minat menggunakan kain batik yang memiliki motif lepasan corak abstrak dengan warna yang cerah daripada motif klasik yang menjadi ciri khas. Dinamika ini berkembang seirama dengan perkembangan konsumen yang dinamis, menginginkan sesuatu yang baru, tetap mengedepankan kepuasan dan terpapar tren mode dunia. Penyesuaian transformasi inovasi diperlukan hampir pada semua dunia usaha untuk dapat memenuhi transformasi permintaan yang ditempatkan

Gambar 2

Batik Kontemporer

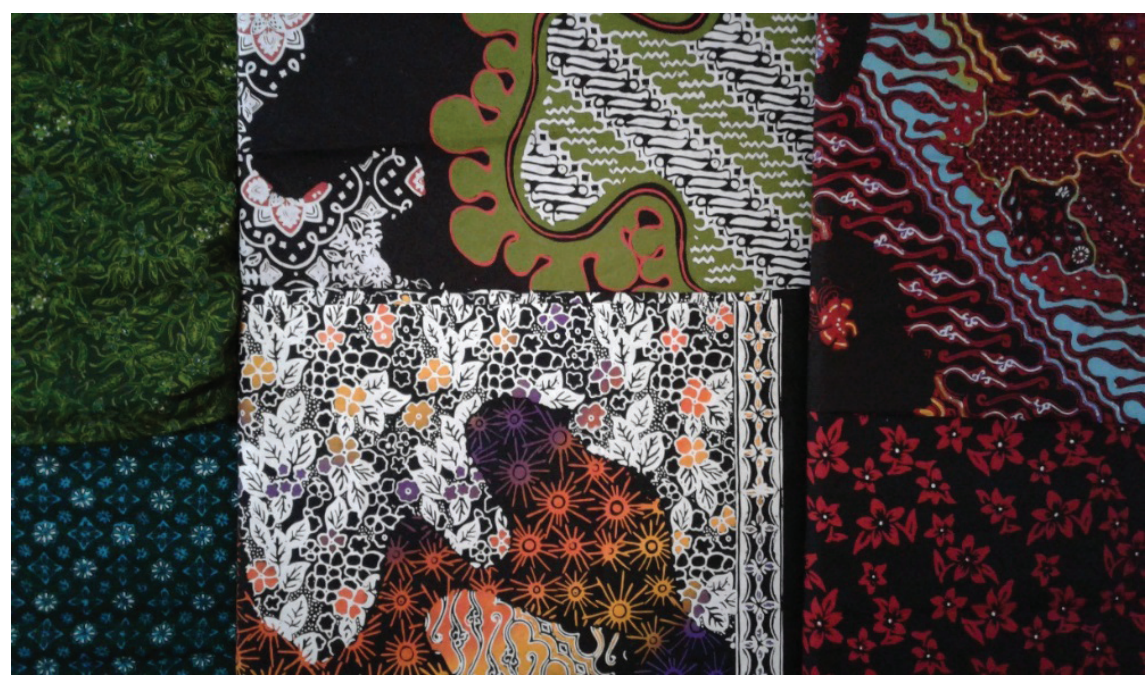

Sumber: Dokumentasi Darto Wahidin, 2018. 
pada skala prioritas utama sebuah perusahaan. Inovasi juga dapat terus berkembang apabila dilakukan transformasi secara terus menerus, hadir dalam ritme kehidupan modern dan mutakhir.

Sesuai dengan peran dari perusahaan yang menghendaki transformasi di segala bidang, maka dimensi dari inovasi dapat dikemukakan oleh Kotler dan Keller (2012), sebagai berikut (1). Main power, merupakan bentuk menyeimbangkan antara kemampuan dengan kebutuhan perusahaan; (2). Materials, penyesuaian antara bahan dasar dengan bahan penunjang lainnya dalam pelaksanaan proses produksi; dan (3). Mechine, dibutuhkan untuk membantu kelancaran proses produksi. Pengembangan inovasi merupakan suatu langkah yang dapat digali terus menerus dan diwujudkan menjadi sebuah ide atau gagasan yang berbentuk produk atau jasa yang sesuai dengan kebutuhan pasar terutama menyikapi konsumen yang dinamis. Produksi dikembangkan menyesuaikan antara bahan baku atau bahan penunjang lainnya terutama mesin yang digunakan untuk kebutuhan proses produksi.

Sehelai kain batik dapat mengungkapkan berbagai filosofi dari mulai lingkungan batik tersebut berasal, siapa yang mengenakannya, dalam kesempatan apa harus dikenakan, dan makna apa yang terkandung di dalam batik tersebut. Sedangkan pada ragam hiasnya dapat menyiratkan dinamika budaya, seirama dengan perjalanan waktu dan lingkungannya. Tak terbatas kreativitas yang bisa menampilkan wajah Indonesia melalui ide dan gagasan, inovasi diperlukan dalam mengekspresikan kemampuan yang dituangkan dalam sebuah karya yang mengangumkan tersebut. Kejelian mengkolaborasikan antara desain-desain pada pola motif yang dikehendaki menghasilkan produk inovatif tanpa harus tunduk kepada pakem atau aturan sebagaimana layaknya kain batik yang selama ini ada. Seiring dengan transformasi zaman dan selera yang harus berkembang bahwa pandangan sebagian besar kalangan terhadap corak batik pun mengalami transformasi.

Sekarang ini kreativitas merupakan sebuah jantung dari industri kreatif dimanapun, tak terkecuali di Indonesia sendiri, yang menciptakan gaya unik dan menarik merupakan tantangan bagi setiap orang yang mencintai dunia seni. Bahkan kreativitas menarik menjadi kata kunci bagi sebagian besar pencetus gagasan tentang mode, karena mode menjadi ranah yang menjelma sebagai sebuah surga kebebasan berimajinasi, berkreasi, dan bergaya. Kreativitas merupakan gagasan baru yang dicetuskan oleh individu atau kelompok untuk memulai sesuatu yang dianggap unik atau beda, melibatkan pemikiran, tenaga, waktu, biaya dengan risiko sukses atau gagal (Griffin, 2009).

$$
\text { Pelatihan yang intensif dapat }
$$
memperbaiki keahlian dan pengetahuan yang tidak terbatas selalu berubah dan dapat diperoleh melalui dimensi kreativitas. Sebagaimana yang diungkapkan oleh Longenecker, dkk (2000), setidaknya ada tiga proses pengembangan kreativitas, yakni (1). Science, disesuaikan dengan kemampuan atau keahlian bagaimana caranya mengembangkan ilmu pengetahuan yang cepat berubah; (2). Technology, yang berkaitan dengan kecanggihan ilmu pengetahuan yang dikembangkan dan diberdayakan; dan (3). Service, pelayanan terhadap pelanggan untuk memberikan kepuasan bagi pelanggannya. Pengembangan kreativitas merupakan sebuah imajinasi yang muncul dalam diri seseorang yang dilengkapi dengan ilmu pengetahuan 
Darto Wahidin, Armaidy Armawi, Kodiran -- Transformasi Industri Kreatif Batik Dalam Rangka Peningkatan Ketahanan Kerajinan Kain Batik (Studi di Dusun Giriloyo, Desa Wukirsari, Kecamatan Imogiri, Kabupaten Bantul, Daerah Istimewa Yogyakarta)

sebagai dasar dari sebuah ide atau gagasan yang akan diciptakannya. Penciptaan ide dapat diwujudkan melalui bantuan perangkat teknologi yang dibutuhkan untuk membantu mempercepat penciptaan ide yang dapat diwujudkan.

Proses kreatif dalam berinovasi menurut Haryono (2008: 49-50) merupakan suatu inovasi yang secara konseptual-teoritis setidaknya memerlukan empat syarat, yaitu: resources, genius, need, dan opportunity. Dari keempat syarat tersebut sesungguhnya memiliki keterkaitan antara satu dengan yang lainnya terhadap batik yaitu adanya ketersediaan sumber bahan (resources) tidak menjamin terjadinya kreativitas pada batik jika tanpa disertai keterampilan dan pengetahuan (genius), tetapi jika masyarakat yang bersangkutan sebagai pendukung budaya tidak merasa memerlukan (need), kreativitas juga tidak terjadi. Meskipun sumber bahan, pengetahuan keterampilan dan kebutuhan untuk memiliki sebuah karya budaya ada. Namun, masyarakat yang bersangkutan sama sekali tidak memiliki kesempatan (opportunity), sebuah kreativitas juga belum tentu terjadi.

Bagi para penganut strukturalisme tidak akan mengacu pada sebab-sebab yang terjadi karena hubungan sebab-akibat merupakan relasi diakronis, tetapi mengacu pada hukumhukum transformasi. Transformasi di sini hendaknya tidak diartikan sebagai perubahan yang berkonotasi historis, diakronis, tetapi sebagai alih rupa. Hukum transformasi merupakan keterulangan-keterulangan (regularities) yang tampak, melalui mana suatu konfigurasi struktural berganti menjadi konfigurasi struktural yang lain (Putra, 2006: 68-69).

\section{Bentuk Transformasi Industri Kreatif Batik Giriloyo}

Terjadinya berbagai macam transformasi industri kreatif batik Giriloyo ternyata menghasilkan berbagai macam bentuk. Bentuk transformasi tersebut bisa dilihat dari adanya transformasi pada pakem, motif, warna, pemasaran, sampai pada ekonomi. Transformasi dilakukan oleh para pengusaha dan perajin batik Giriloyo tersebut dengan dalih agar dapat bersaing dipasaran dan tetap menarik di mata konsumen. Eksistensi batik Giriloyo sangat diperlukan di era modernisasi ini, salah satu cara bereksistensi dengan cara bertransformasi sesuai dengan perkembangan zaman dan mengikuti tuntutan dari konsumen. Sebelum dijelaskan secara rinci, berikut ini tabel 1 meringkasnya untuk mempermudah memahami yang terkait dengan bentuk transformasi industri kreatif batik Giriloyo.

Batik yang ada saat ini telah mengalami transformasi pada pakem-pakem tradisionalnya, pakem yang ada pada batik Giriloyo mendapat pengaruh yang besar dari Keraton Ngayogyakarta. Berbagai motif batik memiliki pakem-pakem tersendiri namun, dalam perkembangannya muncul batik kontemporer yang tidak lagi berpedoman pada pakem-pakem tradisionalnya. Padahal dalam pakem-pakem tradisional terdapat filosofi dan nilai-nilai kehidupan. Bahkan masyarakat kini lebih menyukai batik dengan warna-warna yang cerah ketimbang pakempakem tradisionalnya masih utuh. Tidak jarang perajin batik dalam membuatnya mengabaikan nilai-nilai tradisionalnya karena tuntutan permintaan pengusaha dari konsumen batik.

Pada masa kini motif batik telah berkembang sejalan dengan perkembangan pola pikir manusia, sehingga lahirlah berbagai macam motif batik yang baru. Motif baru 
Tabel 1

Transformasi Industri Kreatif Batik Giriloyo

\begin{tabular}{|c|c|c|c|}
\hline No. & Transformasi & Dulu & Sekarang \\
\hline 1 & Pakem & $\begin{array}{l}\text { Mengikuti pakem aslinya dari Keraton } \\
\text { Ngayogyakarta }\end{array}$ & $\begin{array}{l}\text { Menambahkan pada pakem aslinya yang berasal } \\
\text { dari Keraton Ngayogyakarta }\end{array}$ \\
\hline 2 & Motif & $\begin{array}{l}\text { Masih membuat dengan motif-motif batik } \\
\text { keratonan }\end{array}$ & $\begin{array}{l}\text { Kombinasi dengan motif batik lainnya, sehingga } \\
\text { menghasilkan motif batik kontemporer }\end{array}$ \\
\hline 3 & Warna & $\begin{array}{l}\text { Bahan pewarnaan berasal dari lingkungan } \\
\text { sekitar sentra batik Giriloyo }\end{array}$ & $\begin{array}{l}\text { Terjadinya pecampuran dalam hal proses } \\
\text { pewarnaan antara bahan alam dengan bahan } \\
\text { kimia }\end{array}$ \\
\hline 4 & Pemasaran & $\begin{array}{l}\text { Mekanisme tradisional dengan menjual } \\
\text { kepada jurangan yang ada di sekitar } \\
\text { wilayah Keraton Ngayogyakarta }\end{array}$ & $\begin{array}{l}\text { Mekanisme penjualan modern sudah digunakan } \\
\text { melalui media sosial tapi terkendala oleh sinyal } \\
\text { internet }\end{array}$ \\
\hline 5 & Ekonomi & Hanya sebagai buruh batik & Kesejahteraan lebih terjamin \\
\hline
\end{tabular}

Sumber: Diolah oleh Darto Wahidin, 2019.

tersebut yang menghilangkan nilai-nilai tradisionalnya. Bahkan tidak jarang motif baru tersebut sudah tidak sesuai dengan batik aslinya. Hal ini disebabkan adanya perkembangan dalam dunia industri fashion yang menuntut perajin batik mengikuti perkembangan tersebut. Perajin batik dituntut untuk selalu mengikuti perkembangan industri fashion dan keinginan konsumen yang mengabaikan motif-motif, yang menyebabkan simbol-simbol keasliannya mengalami kehilangan padahal simbol itulah terdapat filosofi kehidupan.

Motif-motif klasik sebenarnya mewarnai sentra batik Giriloyo, motif klasik sendiri sebenarnya berasal dari keraton. Karena memang dulu sejarah adanya batik di Giriloyo karena pengaruh dari pembangunan makam raja-raja Kerajaan Mataram. Secara pakem motif klasik itu tetap mengikuti aturan main dari keraton hingga sekarang. Saat ini para pengusaha dan perajin tersebut menambahi pada ornament dasarnya dan merubah warna. Di sini selain terjadi transformasi warna terjadi pula proses penambahan pada ornament dasarnya yang kebanyakan menambahi dari segi warna pada ornament dasarnya tersebut.

Motif Wahyu Temurun sebagaimana yang ada pada gambar 3, merupakan kategori jenis klasik. Hal tersebut dibuktikan dengan adanya simbol garuda, yang merupakan salah satu simbol dari Keraton Ngayogyakarta. Dasaran pada kain tersebut menggunakan warna hitam, di sini belum tersentuh dengan warna-warna lainnya masih mengikuti pakem aslinya. Motifnya sangat kental sekali dengan kehidupan tradisional yang mempunyai filosofi tinggi, antara lung-lung satu dengan yang lainnya mempunyai nilai filosofi yang sangat tinggi. Motif klasik memang mempunyai nilai filosofi yang begitu tinggi, karena menggambarkan kehidupan pembuatnya pada zaman dulu.

\section{Gambar 3}

Motif Wahyu Temurun Klasik

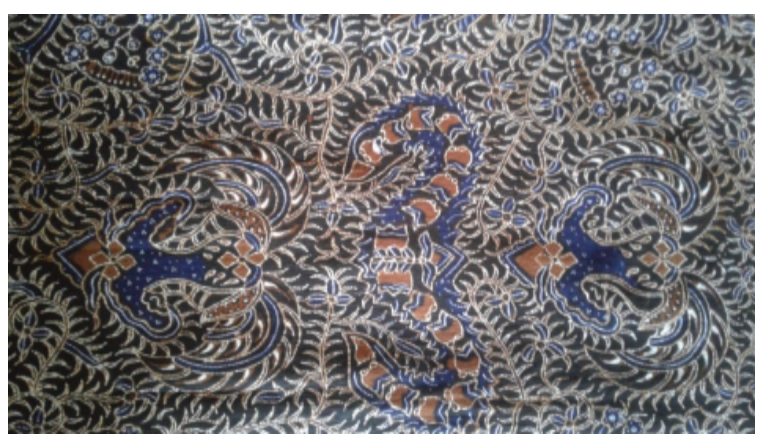

Sumber: Dokumentasi Darto Wahidin, 2018

Transformasi motif, transformasi warna sama improvisasi terjadi dalam batik Giriloyo sebagaimana yang dicontohkan yang ada 
Darto Wahidin, Armaidy Armawi, Kodiran -- Transformasi Industri Kreatif Batik Dalam Rangka Peningkatan Ketahanan Kerajinan Kain Batik (Studi di Dusun Giriloyo, Desa Wukirsari, Kecamatan Imogiri, Kabupaten

Bantul, Daerah Istimewa Yogyakarta)

pada gambar 4 motif Wahyu Temurun yang memainkan warna oleh para perajin secara suka-suka tanpa ada aturan yang berlaku. Proses transformasi tersebut didapatkan dari pengalaman melihat pameran-pameran. Karena manakala dalam satu kain batik terdapat kerumitan yang tinggi dalam hal membuat, mewarnai, lamanya membatik, maupun variasi motifnya banyak, maka akan berpengaruh juga terhadap harga batik itu juga. Di sini terletak suatu hukum yang berlaku dalam batik tulis bahwa semakin tinggi nilai motif batik tersebut, maka akan semakin tinggi juga nilai jualnya.

Gambar 4

Motif Wahyu Temurun Improvisasi

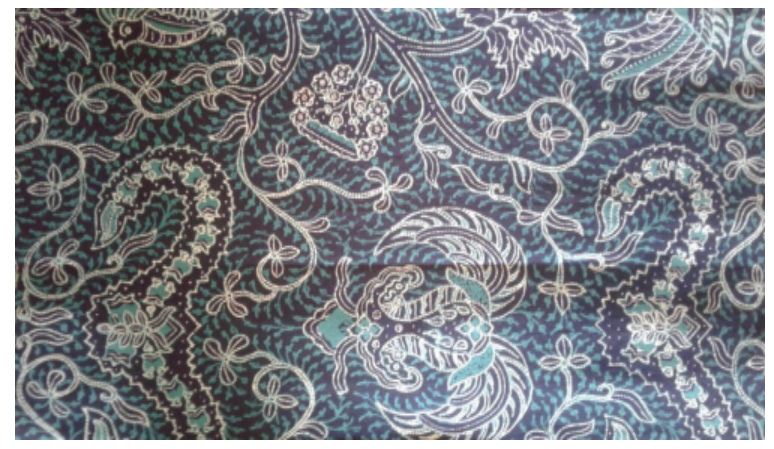

Sumber: Dokumentasi Darto Wahidin, 2018

Motif Wahyu Temurun di atas telah mengalami improvisasi dengan motif lainnya. Memang simbol garuda sebagai ciri motif klasik masih ada dalam kain batik tersebut, walaupun telah mengalami improvisasi dengan yang lainnya. Improvisasi tersebut dengan cara digabungkan dari motif lainnya, terlihat pada gambar terdapat lung-lung yang disambungkan dengan bunga, sehingga bunga akan jauh tampak terlihat dibandingkan dengan lung-lungannya. Dari segi dasaran masih menggunakan warna hitam. Walaupun telah dilakukan improvisasi namun warna yang digunakan tidak terlalu banyak hanya hijau, putih, dan hitam.
Transformasi pewarnaan pada batik menjadi salah satu unsur penting dalam menciptakan batik yang indah. Tak sulit menemukan bahan pewarna batik karena dengan mudahnya akan mendapatkannya di toko-toko yang menjual bahan dan alat-alat keperluan untuk membatik. Namun, terkadang di dalam proses pewarnaan kain batik, banyak pengusaha dan perajin batik yang belum mengolah limbahnya secara benar. Air bekas cucian yang bercampur dengan bahan-bahan kimia termasuk juga bahan pewarna batik, dialirkan begitu saja ke selokan, sehingga akhirnya meleber ke tengah jalan. Bahkan ada juga yang mengalirkannya langsung ke sungai, sehingga sungai tersebut menjadi berubah warna dan menimbulkan bau yang tidak sedap. Limbah tersebut dapat membunuh organisme yang hidup di dalam sungai yang berdampak buruk pada kelangsungan hidup ikan dan hewan lain yang ada di dalamnya. Untuk memperkecil risiko yang ditimbulkan dari limbah batik, penggunaan bahan pewarna alami batik bisa menjadi salah satu pilihan. Selain lebih ramah lingkungan, dengan menggunakan bahan pewarna alami juga dapat menghasilkan warna-warna batik klasik yang alami. Bahan pewarna alami batik bisa didapat dari bahan tumbuh-tumbuhan, buahbuahan, dan daun-daunan yang ada di sekitar lingkungan tempat tinggal. Bahan tersebut bisa berasal dari akar, batang, kulit, daun, bunga maupun buahnya. Dari bahan-bahan tersebut akan dihasilkan warna-warna yang beragam meski tidak selengkap bila menggunakan zat pewarna kimia atau sintesis.

Pewarnaan batik sesungguhnya dapat dibedakan menjadi dua, yaitu: pewarna alam dan pewarna buatan atau sintesis atau kimia. Pewarna alam ini dibuat dari bahan alam, seperti: daun-daunan, kulit kayu, umbi buah, 
dan kulit buah. Sedangkan untuk pewarna sintesis berasal dari bahan zat warna buatan atau zat warna kimia. Sejak diberikannya pelatihan oleh LSM dan dinas yang terkait bahkan juga ada akademisi yang melakukan penelitian terkait dengan kadar air di sentra batik Giriloyo yang sudah tidak sehat lagi, sehingga banyak pengusaha dan perajin yang sadar lalu mencoba mengkombinasikan dalam proses pewarnaan batiknya.

Para pengusaha dan perajin di sentra batik Giriloyo dulu ketika setelah gempa yang melanda Daerah Istimewa Yogyakarta hanya mengenal warna kimia, seperti: warna naptol, warna remasol, dan warna enquisol, karena memang yang dilatih ke para pengusaha dan perajin hanya ketiga warna kimia tersebut. Namun, warna kimia tersebut menimbulkan dampak pencemaran sehingga pemerintah sekarang memperkenalkan warna alami kembali untuk mengurangi pencemaran tersebut. Warna alami tersebut sangat dibutuhkan untuk warna sogan, seperti warna biru dan coklat. Saat ini para pengusaha dan perajin menggunakan dua versi warna yakni warna sintesis dan juga warna alami.

Proses pewarnaan yang menggunakan pewarnaan zat kimia atau sintesis, dalam hal ini menggunakan bahan naptol dan indigosol. Pada dasarnya warna naptol sendiri ada dua jenis ramuan, yaitu: pewarna naptol dengan pembangkit warna garam diazo. Kedua bahan ini tidak boleh dilarutkan tidak boleh bercampur satu dengan yang lainnya. Sedangkan warna indigosol bila ingin digunakan sangat tergantung dengan cuaca yang cerah atau panas karena warna akan muncul dengan baik manakala ada bantuan sinar matahari. Setelah warna muncul, kunci dengan menggunakan larutan HCL (Sukanadi dan Suharson, 2012: 1903).
Dulu di sentra batik Giriloyo yang terkait dengan pewarnaan hanya sebatas warna sintesis. Namun, sekarang lebih tepatnya sejak tahun 2006 atas pendampingan dan pelatihan dari Jepang yang bekerja sama dengan Balai Besar Kerajinan dan Batik Daerah Istimewa Yogyakarta terjadi pendampingan ke arah pewarnaan alami kembali. Warna alami sangat mudah didapatkan karena memang berada di lingkungan sekitar dan tidak menimbulkan pencemaran lingkungan. Sangat berbahaya manakala tiga dusun, yaitu Dusun Karangkulon, Dusun Giriloyo, dan Dusun Cengkehan yang merupakan sentra batik terbesar di Daerah Istimewa Yogyakarta khususnya untuk Dusun Giriloyo sendiri jika para perajinnya menggunakan warna kimia semua. Hal ini akan mengakibatkan rusaknya lingkungan (environment) dan tanah (soil) akibat dari penggunaan warna kimia atau sintesis tersebut. Maka, sejak tahun 2006 dari pelatihan-pelatihan yang dilakukan oleh pihak luar disarankan untuk proses pewarnaan menggunakan dua proses warna yakni warna kimia atau sintesis dan warna alami dengan kesepakatan dari pengusaha, perajin, dan aparat Desa Wukirsari.

Sesungguhnya kreativitas ini sebagai suatu hal yang menghasilkan ide baru oleh individu atau kelompok kecil. Paguyuban Batik Giriloyo sebagai suatu kelompok yang menaungi para pengusaha dan perajin yang ada di sentra batik Giriloyo. Esensi dari kreativitas itu untuk mencipta dengan menggunakan ide, gagasan, dan pikiran yang kreatif. Kreativitas juga melibatkan suatu proses yang dianggap mengandung nilai-nilai kreatif. Proses kombinasi dari warna bahanbahan alam yang dicampurkan oleh para perajin tersebut merupakan bagian dari sebuah kreativitas yang dilakukan. Proses kreatif 
Darto Wahidin, Armaidy Armawi, Kodiran -- Transformasi Industri Kreatif Batik Dalam Rangka Peningkatan Ketahanan Kerajinan Kain Batik (Studi di Dusun Giriloyo, Desa Wukirsari, Kecamatan Imogiri, Kabupaten Bantul, Daerah Istimewa Yogyakarta)

dalam berinovasi menurut Haryono (2008: 49-50), setidaknya ada empat salah satunya terkait dengan ketersediaan sumber bahan (resources). Sadar atau tidak sadar proses pecampuran bahan alam tersebut tentunya mempunyai nilai ekonomis karena lebih hemat, di mana bahan-bahan alam tersebut didapatkan dari lingkungan sekitar sentra batik Giriloyo.

Sebagaimana dalam konsep pemasaran yang diartikan sebagai suatu kegiatan yang mengusahakan agar produk yang dipasarkannya itu dapat diterima dan disenangi oleh pasar (Swastha dan Irawan, 2005). Strategi pemasaran sendiri merupakan logika pemasaran yang dipakai unit bisnis untuk mencapai tujuan pemasaran. Strategi pemasaran yang terdiri dari strategi khusus yang berhubungan dengan pasar sasaran, bauran, pemasaran, dan tingkat pengeluaran pemasaran (Kotler, 1991). Pada dasarnya, tujuan dalam menganut konsep pemasaran untuk memberikan kepuasan kepada konsumen dan masyarakat lain dalam pertukarannya untuk mendapatkan laba, atau perbandingan antara penghasilan dan biaya yang menguntungkan, ini berarti konsep pemasaran mengajarkan bahwa perumusan strategi pemasaran sebagai suatu rencana yang diutamakan untuk mencapai tujuan tersebut, harus berdasarkan kebutuhan dan keinginan konsumennya (Swastha dan Handoko, 2000).

Menurut Gitosudarmo (2000), proses pemasaran merupakan proses tentang bagaimana pengusaha dapat mempengaruhi konsumennya agar konsumen tersebut menjadi tahu, senang, lalu membeli produk yang ditawarkannya dan akhirnya konsumen menjadi puas sehingga mereka akan selalu membeli produknya itu, untuk keperluan tersebut pengusaha dapat melakukan tindakan- tindakan yang terdiri dari 4 macam, yaitu: produk (product), harga (price), promosi (promotion), dan distribusi (placement). Perpaduan antara keempat macam hal itu merupakan senjata bagi pengusaha batik dalam memasarkan produknya yang dikenal sebagai bauran pemasaran atau marketing mix.

Transformasi pemasaran yang terjadi pada batik Giriloyo sesungguhnya telah mengalami perbedaan (difference) dari dulu dan sekarang. Jika dulu proses pemasaran masih bergantung dengan para juragan yang ada di Kota Yogyakarta, lebih tepatnya yang ada di sekitaran daerah Keraton Yogyakarta. Pemasaran tradisional sebagai sebuah bentuk pemasaran dengan cara konvensional yang dipakai sebelum adanya era internet merajalela saat ini. Jenis pemasaran ini paling dikenal oleh banyak publik karena memang sebagian besar manusia di seluruh dunia pasti pernah memakai dan menikmati mekanisme pemasaran tradisional ini. Begitu pula dengan seorang pengusaha dan perajin batik Giriloyo, yang dulu sebagai seorang buruh batik masih sangat tergantung dengan para jurangan batik yang ada di sekitar Keraton Yogyakarta, sehingga hal itu membuat ketergantungan kepada jurangan-jurangan yang ada di Kota Yogyakarta.

Dilihat dari sudut pandang produsen, konsumen individu atau konsumen institusi merupakan bagian penting dalam industri kreatif. Keduanya menyerap produk yang ditawarkan pelaku usaha di arena pasar. Tanpa konsumen tidak mungkin suatu usaha dapat berkembang (Nitisusastro, 2012: 27). Artinya dalam sebuah hubungan membutuhkan lebih dari satu orang dan hubungan tersebut harus mampu dijaga dengan baik agar dapat berkelanjutan. Produsen yang menjalin komunikasi atau hubungan baik dengan 
konsumen memiliki potensi yang besar dalam memajukan usahanya. Strategi pemasaran pada dasarnya merupakan pola langkah atau pola pikir yang harus dijalankan dan harus dijalankan di masa yang akan datang, setidaknya dalam kurun waktu tertentu. Pola pikir dan pola langkah tersebut harus diselaraskan searah dengan tujuan dan sasaran yang ingin dicapai (Nitisusastro, 2012: 13). Maka di sini perlu memahami apa, siapa, dan mengapa, konsumen perlu dipelajari tentang berbagai perbedaan dan kesamaan relatif karakteristik yang melekat pada konsumen (Nitisusastro, 2012: 28).

Namun, sekarang dengan adanya kemudahan akses menuju sentra batik Giriloyo dan adanya kecepatan teknologi turut mempengaruhi akan terjadinya mekanisme proses pemasaran tersebut. Hadirnya teknologi, informasi, dan komunikasi saat ini semakin merambah dalam segi-segi kehidupan masyarakat, sehingga masyarakat mau tidak mau suka tidak suka harus dapat menyesuaikan dengan kehadiran teknologi, informasi, dan komunikasi tersebut. Setidaknya ada lima karakteristik dasar akan hadirnya teknologi, informasi, dan komunikasi sebagaimana yang diungkapkan oleh Castells (2010), bahwa (1). Informasi merupakan bahan baku ekonomi; (2). Teknologi informasi memberikan pengaruh terhadap masyarakat maupun individu; (3). Teknologi informasi memberikan kemudahan dalam pengelolaan informasi yang memungkinkan logika jaringan diterapkan dalam institusi maupun proses ekonomi; (4). Ketika teknologi informasi dan logika jaringan tersebut diterapkan, memunculkan fleksibilitas yang lebih besar dengan konsekuensi bahwa proses, organisasi, dan lembaga ekonomi dengan mudah dibentuk dan terus menerus diciptakan; dan (5).
Teknologi individu telah mengerucut menjadi suatu sistem yang terpadu.

Adanya teknologi, informasi, dan komunikasi tersebut sesungguhnya telah mempengaruhi mekanisme pemasaran dengan cara modern dari para pengusaha batik Giriloyo. Pola pemasaran pun telah mengalami transformasi, karena banyak konsumen yang datang langsung ke sentra batik Giriloyo. Daya tarik paket wisata belajar membatik ternyata telah membuat para konsumen untuk mau belajar karena dari belajar tersebut kemudian banyak juga yang membeli batik di sentra batik Giriloyo. Tapi, dalam pemasaran diam ini sangatlah tidak baik, sehingga tetap harus digunakan pola jemput rezeki juga.

Dalam pemasaran dengan menggunakan internet hanya lewat media sosial, seperti: FB, WA, IG. Tapi, pola penggunaan media sosial tersebut selama ini masih terkendala dengan jaringan internet karena wilayah Dusun Giriloyos sendiri berada di daerah cekungan atau bukit-bukit sehingga sangat sulit untuk menemukan sinyal yang lancar. Padahal Kementerian Komunikasi dan Informatika (Kominfo) sudah membantu dengan fasilitas internet selama enam bulan tapi, selebihnya harus bayar 300.000 per bulannya. Bahkan berbagai startup, seperti: Bukalapak, Lapak. com, Ki-Lapak sudah pernah memberikan pembekalan kepada para pengusaha dan perajin untuk memasarkan produk batik tersebut. Tapi, tidak ada yang terjual karena harganya mahal karena memang yang dijual di Bukalapak itu bentuknya kain batik bukan baju yang harganya murah. Sedangkan di Ki-Lapak para pengusaha enggan memasarkannya lagi karena potongannya mahal sebesar $20 \%$.

Jika melihat berdasarkan pada strategistrategi pemasaran yang diterapkan oleh pengusaha batik Giriloyo dapat dibedakan 
Darto Wahidin, Armaidy Armawi, Kodiran -- Transformasi Industri Kreatif Batik Dalam Rangka Peningkatan Ketahanan Kerajinan Kain Batik (Studi di Dusun Giriloyo, Desa Wukirsari, Kecamatan Imogiri, Kabupaten Bantul, Daerah Istimewa Yogyakarta)

menjadi 4 macam, sebagaimana yang dikemukakan oleh Gitosudarmo (2000), yaitu: produk (product), harga (price), promosi (promotion), dan distribusi (placement), dari keempatnya tersebut sering disebut 4P. Strategi produk yang diterapkan oleh pengusaha dan perajin batik Giriloyo saat ini merupakan hasil produk batik yang tetap mempertahankan keaslian produknya yang dibuat dengan tradisional yang menggunakan warna alami dan sintesis dengan mempertahankan motifmotif klasik. Namun, untuk memperluas selera pasar, pengusaha dan perajin batik Giriloyo juga memproduksi batik kontemporer yang motifnya lebih beragam serta dapat disesuaikan dengan selera konsumen.

Strategi harga yang ditetapkan oleh pengusaha batik Giriloyo cukup mahal. Meski harga batik tersebut ini tergolong mahal, namun para pengusaha batik Giriloyo menekankan pada kualitas batik asli yang tetap dijaga agar pembeli tetap merasa puas pada produk batik dari hasil karya perajinnya. Strategi promosi yang diterapkan oleh pengusaha batik Giriloyo secara umum ada 4 macam, yaitu: dijual secara langsung melalui showroom di rumah pengusaha masing-masing dan di showroom Paguyuban Batik Giriloyo, mengikuti kegiatan pameran, melalui media sosial (website, Email, facebook, whatsApp, instagram), melalui kartu nama, dan melalui leaflet atau brosur. Strategi distribusi terkait dengan saluran pemasaran yang digunakan oleh pengusaha dan perajin di sentra batik Giriloyo pada umumnya dengan sistem penjualan secara langsung. Rantai pemasarannya dari pengusaha dan perajin batik Giriloyo langsung kepada konsumen.

Penelitian sebagaimana Nursaid dan Armawi (2016) lakukan bahwa salah satu upaya dengan pengoptimalan pemasaran berbagai produk batik tulis Giriloyo dengan bekerja sama dengan dinas dan instansi pemerintah; pendampingan pembuatan sistem laporan keuangan; menjalin komunikasi dengan berbagai pihak untuk perbaikan aksesibilitas, menjalin komunikasi intens dengan provider dan Pemerintah Kabupaten Bantul untuk menyediakan jaringan internet dan jaringan komunikasi; serta kerja sama dengan pemerintah untuk pendidikan dan proses regenerasi. Saat ini jaringan internet sangat diperlukan apalagi bagi industriindustri kerajinan kecil kain batik.

Saat ini yang menjadi pengusaha batik Giriloyo dulunya memang sebagai seorang buruh batik. Dari buruh batik tersebut sesungguhnya kehidupannya sangat mengenaskan dan memprihatinkan. Namun, sejak gempa bumi tahun 2006 yang melanda Daerah Istimewa Yogyakarta para buruh tersebut ada sedikit peningkatan dalam membatik walaupun statusnya masih sebagai buruh. Dalam rangka pengembangan ekonomi daerah yang bertujuan untuk meningkatkan kesejahteraan masyarakat maka pengembangan ekonomi lokal sesuai potensinya menjadi sangat penting. Dengan keunggulan yang dimiliki, UKM menjadi sangat penting untuk mewujudkan pengembangan perekonomian daerah dan pemberdayaan masyarakat. Sebagai bagian dari usaha kecil dan menengah serta bagian dari industri kreatif, batik perlu dikembangkan dengan mentransformasikan untuk mewujudkan program pengembangan ekonomi daerah. Hal ini dilakukan dalam rangka mengembangkan potensi daerah Kabupaten Bantul dan kreativitas masyarakat sehingga dapat menghasilkan produk yang mempunyai keunggulan untuk dapat bersaing (competitive advantage).

Menurut Demibag, dkk (2006), bahwa keberhasilan usaha kecil dan menengah (small 
medium enterprises) memiliki dampak langsung terhadap pembangunan ekonomi baik pada negara maju maupun negara berkembang. Usaha kecil dan menengah memiliki kemampuan untuk menciptakan lapangan kerja dengan biaya minimum bahkan UKM merupakan pelopor dalam dunia inovasi yang memiliki fleksibilitas tinggi yang memungkinkan usaha tersebut untuk memenuhi kebutuhan pelanggan (Brock dan Evans, 1986; Acs dan Audretsch, 1990). Menuju kegiatan ekonomi yang memiliki nilai tambah dan berdaya saing tinggi, UKM membutuhkan strategi pengembangan yang terintegrasi sehingga UKM tidak hanya memiliki keunggulan komparatif tetapi juga memiliki keunggulan kompetitif. UKM batik perlu memiliki keunggulan komparatif dan kompetitif agar dapat bertahan dan bersaing dalam menghadapi persaingan global. Karakteristik UKM yang memiliki keunggulan kompetitif sebagaimana yang diungkap oleh (Tambunan, 2009) sebanyak sembilan, sebagai berikut: memiliki kualitas SDM yang baik; pemanfaatan teknologi yang optimal; mampu melakukan efisiensi dan meningkatkan produktivitas; mampu meningkatkan kualitas produk; memiliki akses promosi yang luas; memiliki sistem manajemen kualitas yang terstruktur; memiliki sumber daya modal yang memadai; memiliki jaringan bisnis yang luas; dan memiliki jiwa kewirausahan. Dari sembilan karakteristik tersebut UKM harus memiliki semua unsurunsurnya agar mampu bersaing dengan berbagai macam keunggulan yang komparatif dan kompetitif.

\section{Dampaknya Terhadap Peningkatan Ketahanan Kerajinan Kain Batik}

Batik sebagai sebuah produk kerajinan tentunya harus mampu bersaing dengan produk-produk kerajinan lainnya. Keberadaan kerajinan kain batik di suatu daerah tentunya melahirkan ekspresi seni, gagasan kreatif, produktif yang memiliki ciri atau karakteristik yang spesifik atau khas sesuai jenis dan model produk yang dihasilkannya. Kerajinan kain batik berkembang dalam kelompok masyarakat yang menempati strata sosial tertentu, yang memiliki kemampuan untuk memanfaatkan dan menikmati sumber daya lingkungan dengan maksimal seperti para elit pengusaha dan pemilik modal (Rohidi, 2000). Dengan adanya arus modernisasi yang berkembang begitu pesat kerajinan kain batik di daerah harus mampu bersaing. Solusinya dengan melalui peningkatan ketahanan kerajinan kain batik itu sendiri.

Kerajinan kain batik dapat diapresiasi sebagai dampak dari adanya interaksi dari para pengusaha dan perajin, dunia usaha dalam membaca kebutuhan dan keinginan konsumen sehingga produk yang dihasilkan dapat memuaskan dan diminati oleh orang lain sebagai penggunaan. Di sisi lain, transformasi industri kreatif batik telah memberikan dampak yang positif bagi produksi kain batik itu sendiri dan kesejahteraan terhadap perajinnya. Namun, setiap usaha proses transformasi industri kreatif batik yang dilakukan juga memiliki dampak yang berkaitan dengan penyediaan material atau bahan yang digunakan, dan kualitas teknis dalam pembuatannya.

Setidaknya para pengusaha dan perajin batik Giriloyo telah merasakan dampak positif dari berjualan batik dulu hingga sekarang. Tak jarang dari berjualan batik tersebut para pengusaha dan perajin dapat mencukupi kebutuhan sehari-harinya agar tetap bertahan hidup. Berdasarkan hasil di lapangan menunjukkan bahwa terjadinya peningkatan produksi batik dan kesejahteraan 
Darto Wahidin, Armaidy Armawi, Kodiran -- Transformasi Industri Kreatif Batik Dalam Rangka Peningkatan Ketahanan Kerajinan Kain Batik (Studi di Dusun Giriloyo, Desa Wukirsari, Kecamatan Imogiri, Kabupaten Bantul, Daerah Istimewa Yogyakarta)

lebih terjamin yang dirasakan oleh pengusaha dan perajin selama ini. Para pengusaha atau ketua kelompok batik tersebut dulunya memang sebagai seorang buruh batik, dari buruh tersebut yang hidupnya serba tidak enak dan pas-pas dalam mencukupi kebutuhannya karena hanya diberi upah Rp 10.000 yang tidak bisa mencukupi kebutuhan sehariharinya, apalagi ketika krisis melanda negara Indonesia yang membuat semakin terpuruk karena tidak bisa membatik disebabkan harga bahan baku naik drastis sehingga sangat sulit dalam memenuhi kebutuhan sehari-hari karena tidak ada pemasukan untuk uang dapur. Kemudian terjadi gempa tahun 2006 membuat proses produksi itu terhenti, karena proses terhenti tersebut lalu dibangkitkan lagi dengan masuknya LSM dan dinas yang terkait untuk melakukan berbagai macam pelatihan terhadap perajin.

Dari pelatihan-pelatihan tersebut kemudian dimanfaatkan untuk menggelorakan semangat untuk maju dan sejak saat itu kemudian bertransformasi dari yang dulunya sebagai seorang buruh kemudian dengan adanya sedikit modal atas pinjaman dari pihak bank dan diberikan alat-alat oleh pihak terkait, kemudian memberanikan diri untuk membentuk kelompok dan sebagai ketuanya yang otomatis dari ketua tersebut akan menjadi seorang pengusaha batik Giriloyo. Turun naiknya perkembangan batik bagi pengusaha batik Giriloyo menjadi hal wajar karena ada pengaruh gelombang tidak menentu yang terjadi sehingga menimbulkan dampak terhadap pengusaha batik Giriloyo, salah satu terjadinya peningkatan produksi batik di sentra batik Giriloyo.

Para pengusaha dan perajin batik Giriloyo memperoleh wawasan pengetahuan, misalnya para pengusaha dan perajin tersebut mulai melakukan pengembangan terhadap motif-motif klasik batik Giriloyo ke arah batik kontemporer yang digemari oleh kalangan generasi muda, kemudian terjadi juga pengembangan terhadap desain motif batik Giriloyo tersebut bahkan adanya wawasan pengetahuan yang baru terkait dengan pewarnaan yang memberikan dampak pada lingkungan sekitar sentra batik Giriloyo. Dilakukannya pengembanganpengembangan tersebut tentunya membawa ke arah perkembangan perekonomian yang lebih baik dan maju dari para pengusaha dan perajin batik Giriloyo itu sendiri.

Adanya keunggulan di tiap dusun yang ada di Desa Wukirsari menjadikan Desa Wukirsari sebagai desa wisata yang tentunya memberikan dampak positif yang sangat besar utamanya bagi tiga dusun yang merupakan sentra batik Giriloyo, kunjungan yang datang ke sentra batik Giriloyo setiap tahunnya sudah mencapai 24.000 pengunjung. Kebanyakan pengunjung yang datang ke sentra batik Giriloyo tersebut merupakan anak-anak sekolah yang mengambil paket belajar membatik, dalam satu rombongan bisa mencapai 300 anak sekolah. Dari 300 anak sekolah tersebut, akan dibuat kelompok di mana satu kelompok terdiri dari 5 anak sekolah yang akan didampingi oleh satu perajin batik Giriloyo, sehingga dibutuhkan 60 perajin batik untuk mendampingi anak sekolah tersebut. Tentunya adanya pendampingan dari pengusaha dan perajin tersebut telah memberikan peningkatan ekonomi bagi para pengusaha dan perajin batik Giriloyo khususnya, bahkan masyarakat sekitar yang berjualan sudah merasakan akan hal tersebut dari adanya pengunjung yang datang di sentra batik Giriloyo. Peningkatan ekonomi bagi para pengusaha dan perajin lainnya dibuktikan 
dengan kepemilikan sepeda motor ditiap rumah yang mempunyai lebih dari satu bahkan empat sepeda motor, berbeda dengan dulu yang hanya mempunyai satu sepeda motor. Bahkan para pengusaha batik Giriloyo sudah banyak yang memiliki mobil pribadi, berbeda dengan dulu yang sama sekali tidak memiliki mobil.

Pengusaha batik telah menjanjikan sebuah kesejahteraan yang lebih baik bagi para pengusaha batik manakala batik tersebut cepat terjual sehingga keuangan pun akan dengan mudah diputar kembali bahkan bagi pengusaha yang punya konsumen dengan selalu berlangganan, maka akan dengan mudah untuk menjualnya. Para perajin di sentra batik Giriloyo saat ini dalam satu kain batik bisa mengelola sendiri dari mulai awal hingga akhir. Pembelajaran pengelolaan batik dari mulai awal sampai akhir tersebut didapatkan dari pelatihan-pelatihan yang diadakan oleh CSR maupun dinas ataupun kementerian. Dengan adanya proses pengelolaan batik sendiri tersebut akan mempengaruhi terhadap pendapatan dari masing-masing perajin. Pendapatan para perajin saat ini memang telah mengalami kenaikan karena memang pendapatannya bukan hanya dari batik saja tapi, juga dari kunjungan para wisatawan yang berkunjung ke sentra batik Giriloyo dengan mengambil paket belajar membatik.

Sebagaimana yang diungkapkan dalam penelitiannya Nursaid dan Armawi (2016) yang melakukan studinya pada kelompok batik tulis Sekar Arum di Dusun Giriloyo bahwa dibuatnya kelompok-kelompok di sentra batik Giriloyo agar dapat membuat kesejahteraan terhadap para perajin yang ada di kelompoknya masing-masing. Karena dari kelompok batik tulis tersebut dapat dijadikan sebagai obyek wisata alternatif dan tempat pendidikan serta kelompok batik sebagai jembatan kesejahteraan. Bahkan dalam kelompok batik tulis Sekar Arum tersebut ternyata telah berhasil mewujudkan ketahanan ekonomi pada keluarga masing-masing perajin yang ada di kelompok tersebut.

Selain adanya dampak positif tentunya juga ada dampak negatifnya dari proses transformasi industri kreatif batik selama ini dan hal itu dirasakan oleh para pengusaha dan perajin batik Giriloyo. Beberapa hal yang selama ini dirasakannya, yakni: adanya limbah pewarnaan batik dan adanya penjiplakan batik tulis yang dilakukan oleh orang lain. Peningkatan industri kreatif batik di sentra batik Giriloyo ini tidak diikuti dengan proses pengolahan limbah yang baik. Pada kenyataannya menurut Gomez, dkk (2008) bahwa setiap industri merupakan sumber penyumbang polutan ke badan air dalam jumlah yang besar. Limbah yang dihasilkan dapat berupa limbah organik maupun limbah anorganik yang dapat mempengaruhi karakteristik badan air. Bahkan sebagaimana yang disampikan oleh Walker, dkk (2006) jika terus dibiarkan tentunya polutan tersebut tidak hanya terakumulasi di air namun juga pada sedimen dan menyebabkan terganggunya sistem rantai makanan yang ada di perairan tersebut. Pada proses pembuatan batik terdapat beberapa kegiatan yang dapat menghasilkan limbah ke lingkungan, pada proses nganji dan proses pencelupan atau pewarnaan. Proses tersebut merupakan penyumbang zat paat tersuspensi di perairan di antaranya BOD dan COD, selain itu zat pewarna juga sangat berpengaruh dalam pencemaran lingkungan yang dihasilkan oleh limbah batik (Sumarno dkk, 1999).

Tanpa disadari oleh para pengusaha dan perajin batik Giriloyo sebenarnya ada 
Darto Wahidin, Armaidy Armawi, Kodiran -- Transformasi Industri Kreatif Batik Dalam Rangka Peningkatan Ketahanan Kerajinan Kain Batik (Studi di Dusun Giriloyo, Desa Wukirsari, Kecamatan Imogiri, Kabupaten

Bantul, Daerah Istimewa Yogyakarta)

dampak negatif yang begitu besar yakni terkait dengan limbah dari pewarnaan batik tersebut, terutama dari pewarnaan sintesis atau kimia. Dan hal tersebut tidak disadari oleh pengusaha dan perajin batik Giriloyo sendiri, yang disadari hanya mendapatkan untung yang besar dan terjual cepat dari proses penjualan batiknya. Kemudian ketika ada penelitian yang dilakukan oleh Mahasiswa UPN Veteran Yogyakarta tahun 2013 yang meneliti terkait dengan kultur tanah seberapa besar tercemarnya dari limbah pewarnaan batik. Hasil penelitian tersebut menemukan bahwa kultur tanah di tiga dusun sentra batik Giriloyo sudah tercemar sangat tinggi oleh limbah batik.

Sebuah produk begitu mudahnya diduplikat atau dijiplak oleh orang lain karena saat ini adanya kemajuan teknologi yang melingkupinya sehingga segala sesuatunya sangat mudah dilakukan sebuah peniruan tanpa mengenal belas kasihan akan karya yang dilakukan oleh orang aslinya atau orang yang menciptakannya. Hal ini pun terjadi pada sebuah karya seni batik, sehingga membuat pengusaha dan perajin merasakan kekecewaan yang mendalam karena batik yang diproduksinya merupakan batik tulis dengan pengerjaan waktu lama, kemudian dengan cepatnya dilakukan duplikat dan jiplak oleh orang lain.

Teknologi yang berkembang begitu pesat saat ini tentunya membawa pengaruh pada pembuatan batik itu sendiri, padahal batik yang benar dan betul harus melalui proses perintangan warna dengan menggunakan malam atau lilin. Tanpa melalui proses tersebut maka dapat dikatakan bahwa itu bukan batik tulis melainkan batik cap atau batik printing. Bahkan untuk batik cap kombinasi pun masih ada proses perintangan warnanya.
Dengan adanya teknologi yang canggih begitu mudahnya dalam menduplikat sebuah produk, batik tulis yang memerlukan waktu paling cepat satu bulan bahkan ada yang sampai dua hingga tiga bulan. Batik tulis tersebut diduplikat dalam hitungan menit sudah jadi, ini yang dinamakan batik printing. Kemudian printing tersebut dijual pada pasaran dengan harga yang murah bahkan warnanya sangat bagus dan yang parahnya lagi masyarakat tidak bisa membedakan mana batik tulis mana batik printing, yang masyarakat tahu batik tersebut warnanya bagus dan harganya murah sehingga dibeli saja. Pola penghargaan terhadap budaya batik sangat rendah, karena tidak menghargai perajin batik tulis itu sendiri.

\section{SIMPULAN}

Berdasar penjelasan tersebut di atas dapat ditarik simpulan sebagai berikut.

Pertama, transformasi industri kreatif batik Giriloyo yang terjadi ternyata keberadaannya selama ini dipengaruhi oleh gejolak tantangan perkembangan zaman dari tahun ke tahun. Tantangan yang sangat berat dalam melakukan transformasi industri kreatif terletak pada sumber daya manusia (human resources) serta infrastruktur teknologi dan komunikasi. Ruang spasial sentra batik Giriloyo ternyata belum terdukung dengan baik dari infrastruktur jaringan internet. Padahal kunci dari sebuah kreativitas agar dapat berdaya saing tinggi terletak pada sumber daya manusia (human resources) kreatif yang mengikuti perkembangan zaman dan pemanfaatan teknologi yang optimal untuk sebuah proses pemasaran.

Kedua, terjadinya transformasi industri kreatif batik Giriloyo telah memberikan bukti nyata adanya peningkatan terhadap ketahanan kerajinan kain batik melalui peningkatan 
produksi kerajinan kain batik Giriloyo dan kesejahteraan yang terjamin terhadap pengusaha dan perajin. Namun, di sisi lain memberikan pencemaran terhadap lingkungan (environment) dengan adanya limbah industri batik serta dengan begitu mudahnya terjadinya penjiplakan terhadap batik tulis Giriloyo. Gempuran kerajinan kain batik yang berasal dari luar negeri yang ada di pasaran Daerah Istimewa Yogyakarta membuat batik Giriloyo harus mampu bertahan dan bersaing dengan berbagai macam keunggulan yang dimilikinya secara komparatif dan kompetitif.

Berdasarkan simpulan tersebut, penelitian ini mempunyai rekomendasi yang ditujukkan kepada pihak-pihak terkait.

Pertama, perlunya kemudahan akses yang diberikan oleh provider jaringan internet yang menangani masalah teknologi dan komunikasi terhadap infrastruktur jangkauan akses internet, karena berkaitan dengan proses pemasaran menggunakan mekanisme modern melalui media elektronik dan media sosial.

Kedua, intensitas keterlibatan Pemerintah Daerah Istimewa Yogyakarta dan Kabupaten Bantul dalam memasarkan batik Giriloyo baik di dalam negeri maupun di luar negeri sangat diperlukan, selain untuk mempromosikan juga dapat meningkatkan ketahanan kerajinan kain batik.

Ketiga, pentingnya pelatihan terhadap pengusaha dan perajin batik Giriloyo mengenai pewarnaan yang ramah lingkungan terutama oleh Dinas Lingkungan Hidup maupun kalangan akademisi yang peduli terhadap lingkungan.

Keempat, masyarakat harus dapat memahami dengan baik dan benar terhadap perbedaan dari batik tulis, batik cap kombinasi, batik cap, dan batik printing. Dengan mengetahui perbedaannya tersebut maka masyarakat tidak akan mengalami kesalahan dalam membeli batik.

Kelima, perlunya regenerasi kepada generasi muda dengan cara memasukkan dan mewajibkan proses pembelajaran membatik dalam kurikulum maupun ekstrakulikuler di sekolah-sekolah yang ada di Daerah Istimewa Yogyakarta, agar batik tidak punah ditengah gempuran kerajinan kain batik yang berasal dari luar negeri dan batik tetap bisa bertahan serta bersaing.

\section{DAFTAR PUSTAKA}

Acs, Z., and Audretsch, D., 1990, The Economics of Small Firms: A European Challenge, Norwall MA: Kluwer Academic Publishers.

Brock, W., and Evans, D., 1986, The Economics of Small Business: Their Roles and Regulations in US Economy, Teaneck NJ: Holmes and Meier Publishers.

Castellz, M., 2010, The Information Age, Economy, Society, and Culture, Malden MA: Blackwell Publishing Ltd.

Creswell, John W., 2013, Research Design: Pendekatan Kualitatif, Kuantitatif, dan Mixed, Yogyakarta: Pustaka Pelajar.

Daszko, M., and Sheinberg, 2005, Survival is Optional: Only Leaders With New Knowledge Can Lead the Transformation.

Demirbag, M., Tatoglu, E., Tekinsus, M., and Zaim, S., 2006, “An Analysis of The Relationship Between TQM Implementation and Organizational Performance: Evidence From Turkish SMEs", Journal of Manufacturing Technology Management, Vol. 7, No. 6, hal. 829 - 847.

Departemen Perdagangan Republik Indonesia, 2008, Pengembangan Ekonomi Kreatif Indonesia tahun 2025: Rencana 
Darto Wahidin, Armaidy Armawi, Kodiran -- Transformasi Industri Kreatif Batik Dalam Rangka Peningkatan Ketahanan Kerajinan Kain Batik (Studi di Dusun Giriloyo, Desa Wukirsari, Kecamatan Imogiri, Kabupaten Bantul, Daerah Istimewa Yogyakarta)

Pengembangan 14 Sektor Industri Kreatif Indonesia (2009-2015), Jakarta: Departemen Perdagangan Republik Indonesia.

Gitosudarmo, Indriyo, 2000, Manajemen Pemasaran, Yogyakarta: BPFE Yogyakarta.

Gomez, N., Sierra, M. V., Cortelezzi, A., and Capitulo, A. R., 2008, "Effect of Dischanges From the Textile Industry on the Biota Integrity of Benthic Assemblages", Ecot. Env. Saf. Vol. 69, No. 3, hal. 472 - 479.

Griffin, Jill, 2009, "Taming the Search and Swith Customer: Earning Customer Loyalty in a Compulsion to Compare World", John Wiley and Sons.

Haerisma, Alvien Septian, 2018 ,

"Pengembangan Ekonomi KreatifBidang Fashion Melalui Bauran Pemasaran", AlAmwal, Vol. 10, No. 1, hal. 91 - 104.

Haryono, Timbul, 2008, Seni Pertunjukkan dan

Seni Rupa dalam Perspektif Arkeologi Seni, Surakarta: ISI Press Solo.

Hikmah, Isfi Laili Nur, 2017, "Peran Kelompok

Pengrajin Batik Terhadap Pengembangan

Desa Wisata Batik Giriloyo", Pendidikan

Sosiologi, hal. 10 - 21.

Kotler and Keller, 2012, A Famework for

Marketing Management, Prentic Hall

International Inc: New Jersey.

Longenecker, Moore, Petty, 2000, Small

Business Management, South western:

College Publishing.

Martono, Nanang, 2014, Sosiologi Perubahan

Sosial, Jakarta: PT Raja Grafindo

Persada.

Maziyah, Siti, dkk, 2016, "Makna Simbolis

Batik pada Masyarakat Jawa Kuna", Jurnal Paramita, Vol. 26, No. 1, hh. $23-32$.
Miles, Matew B., dan Huberman A. Michael., 1992, Sumber tentang Metode-Metode Baru, Jakarta: UI Press.

Nitisusastro, Mulyadi, 2012, Perilaku Konsumen dalam Perspektif Kewirausahaan, Bandung: Alfabeta.

Nurcahyanti, Desy dan Affanti, Tiwi Bina, 2018, "Pengembangan Desain Batik Kontemporer Berbasis Potensi Lokal dan Kearifan Lokal", Jurnal Sosioteknologi, Vol. 17, No. 3, hh. 391 - 402.

Nurficahyanti, Fera, 2015, "Model Komunikasi Pemasaran Paguyuban Batik Tulis", Jurnal Komunikasi ASPIKOM, Vol. 2, No. 5, hh. 304 - 313.

Nursaid, Arif dan Armawi, Armaidy, 2016, "Peran Kelompok Batik Tulis Giriloyo dalam Mendukung Ketahanan Ekonomi Keluarga (Studi di Dusun Giriloyo, Desa Wukirsari, Kecamatan Imogiri, Kabupaten Bantul)", Jurnal Ketahanan Nasional, Vol. 22, No. 2, hh. 217 - 236. Oakley, K. 2009, “The Disappearing Arts: Creativity and Innovation After the Creative Industries", International Journal of Cultural Policy, Vol. 15, No. 4, hh. 403 - 413.

Poloma, Margaret M., 2002, Sosiologi Kontemporer, Jakarta: Raja Grafindo Persada.

Purwaningsih, Ernawati, 2010 , "Pengembangan Ekonomi Kreatif Desa Wisata Candirejo", Jurnal Jantra, Vol. V, No. 9, hh. 783 - 792.

Putra, Heddy Shri Ahimsa, 2006 , Strukturalisme Levi-Strauss: Mitos dan Karya Sastra, Yogyakarta: Kepel Press. Rohidi, T. R., 2000, Kesenian dalam Pendekatan Kebudayaan, Bandung: STSI. 
Rosalina, Monica dan Martinelli, Imelda, 2013, "Pemaknaan Motif Batik Jogja dan Batik Solo". Jurnal komunikasi Universitas Tarumanagara, Vol. V, No. 01, hh. 129 - 142.

Soekamto, Chandra Irawan, 1984, Pola Batik, Jakarta: CV Akadoma.

Steelyana, Evi, 2012, "Batik a Beautiful Cultural Heritage that Preserve Culture and Support Economic Development in Indonesia”, Binus Business Review, Vol. 3, No. 1, hh. $116-130$.

Sternberg, Robert J., 1999, Handbook of Creativity, London: Cambridge University Press.

Sukanadi, I Made., dan Suharson, Arif, 2012, "Batik Bantul di Sentra Batik Giriloyo dan Wijirejo Bantul", Jurnal Riset Daerah, Vol. XI, No. 3, hh. 1893 - 1915. Sumarno, Sumantri, Indro, Meng, 1999, Pengelolaan Limbah Cair Industri Kecil
Batik dengan Bak Anaerobik Berserat, Semarang.

Swastha, Bayu dan Handoko, T. H., 2000, Manajemen Pemasaran: Analisa Perilaku Konsumen, Yogyakarta: BPFE - Yogyakarta.

Swastha, Bayu dan Irawan, 2005, Manajemen Pemasaran Modern, Yogyakarta: Liberty Yogyakarta.

Tambunan, Tulus, 2009, UMKM di Indonesia dan Beberapa Isu Penting, Jakarta: Ghalia Indonesia.

Wahidin, Darto, dan Sarmini, 2016, "Transformasi Makna Batik Cirebon: dalam Perspektif Politik Negara dan Simbol Identitas", Kajian Moral dan Kewarganegaraan, Vol. 2, No. 4, hh. $663-677$.

Walker, C., Hopkin, S., Sibly, R., and Peakall, D., 2006, Principles of Ecotoxicology, New York: CRS Press: Taylor and Francis Group LCC London. 